\title{
Effect of Contact with Patients on Attitudes of Student Nurses Towards the Mentally Ill
}

\section{Fakhr El-Islam $\mathbf{M}^{1^{*}}$ and Radwa El-Attar ${ }^{2}$}

${ }^{1}$ FRCP, FRCPsych, Behman Hospital, Helwan, Cairo, Egypt

${ }^{2}$ Registrar Behman Hospital, Helwan, Cairo, Egypt

"Corresponding author: Dr M Fakhr El-Islam. FRCP, FRCPsych, Academic Consultant Behman Hospital, Helwan, Cairo, Egypt, Tel: +20 2 25557551; E-mail: Info@behman.com

Rec date: July 6, 2017; Acc date: July 12, 2017; Pub date: July 20, 2017

Copyright: (c) 2017 Fakhr El-Islam M, et al. This is an open-access article distributed under the terms of the Creative Commons Attribution License, which permits unrestricted use, distribution, and reproduction in any medium, provided the original author and source are credited.

\begin{abstract}
Introduction: Studies of social attitudes towards the mentally ill revealed their down-casting as untrustworthy, ineffective and even dangerous. It is hypothesized that contact with patients is associated with an increase in favourable attitudes towards the mentally ill.
\end{abstract}

Method: An attitude test was administered to student nurses before and after their psychiatric nurse training rotation.

Results: A significant increase in favourable attitudes was found at the expense of a reduction in undecided and unfavourable attitudes.

Discussion: The social down-casting of the mentally was reflected in student nurse's initial attitudes towards the mentally ill as dangerous and unreliable or at least unproductive human beings.

Conclusion: Contact with patients during training elicited empathy of trainee nurses and this was reflected in more favourable attitudes towards the mentally ill and the correction of unfavourable or undecided attitude of awe, untrustworthiness, unpredictability and even dangerousness derived from the culture from which the student nurses come.

Keywords: Mental stigma; Student nurses; Psychiatric training

\section{Introduction}

Mental stigma is the social down-casting of the mentally ill. Scales introduced to measure this attitude were adapted to the Arab culture by Kadri [1] in Morocco and by Sidhom et al. [2] in Egypt. The present study tests the hypothesis that contact with mentally ill patients is associated with favourable attitude changes among student nurses.

\section{Method}

The subjects of this study were student nurses from the high nursing institute in Al-Gouna, Hurgada, Egypt who spent an 8-week psychiatric training rotation in the Behman psychiatric hospital, Cairo (June 2015 to August 2015)

Student nurses completed an attitude questionnaire before and after their rotation in this hospital. The questionnaire used was the Bartlett et al. [3] scale which was published as exhibit 9-21 in scales for measurement of attitude [4]. The test was presented to students in its original English language after re-wording to apply to the mentally ill rather than the mentally retarded. This test was thought to have facevalidity because most of its items are included in the scales used by Kadri [1] and Sidhom et al. [2] For 24 attitude statements nurse students expressed approval, disproval or indecision.

\section{Results}

Students included 8 males and 2 females aged 20 years to 22 years. Students and their training supervisors agreed to the study which was considered ethical by the hospital review board. Table 1 shows the total of students' favourable, unfavourable and undecided attitudes before and after their psychiatric training rotation.

\begin{tabular}{|l|l|l|l|}
\hline Attitudes & Before rotation & After rotation & Total \\
\hline Favourable & 65 & 140 & 205 \\
\hline Unfavourable & 110 & 88 & 198 \\
\hline Undecided & 65 & 12 & 77 \\
\hline Total & 240 & 240 & 480 \\
\hline 2 df $X 2=44.0 \quad P<0.001$ & & \\
\hline
\end{tabular}

Table 1: Attitudes sum totals of student nurses before and after their rotation.

Favourable attitudes were significantly increased after student nurses' contact with mentally ill patients throughout their psychiatric training rotation. The increase in favourable attitudes was mainly at 
Citation: El-Islam MF and El-Attar R (2017) Effect of Contact with Patients on Attitudes of Student Nurses Towards the Mentally III. J Socialomics 6: 211. doi:10.1472/2167-0358.1000211

Page 2 of 2

the expense of reduction of the undecided responses. The study is confirmed.

\section{Discussion}

Students' initial attitudes reflect the attitudes of the community in general which are based on anecdotal and media information about the myth of mental illness. In the Arab society, mental illness is still attributable to supernatural agents known as jinn (demons) which are alleged to break patient's contact with reality and break their reasoning.

The social down-casting of the mentally was reflected in student nurse's initial attitudes towards the mentally ill as dangerous and unreliable or at least unproductive human beings.

\section{Conclusion}

Contact with patients not only reduced the awe of students but also demonstrated how treatment restored their pre-morbid selves to varying degrees. Students empathized with patients who had mental suffering that interrupted their social adaptation, productivity and independence. Our findings echo those reviewed by Kadri [1] in medical students' before and after their psychiatric rotation.

\section{References}

1. Kadri N (2005) Schizophrenia and stigma: A transcultural perspective. In O Kasha A, Stefanis CN (eds). Perspectives on the stigma of mental illness. Geneva: World Psychiatric Association. pp. 52-58.

2. Sidhom E, Abdel FA, Carter JM, El-Dosoky A, El-Islam MF (2014) Patients' perspectives on stigma of mental illness. 65: 166.

3. Bartlett CJ, Quay LC, Wrightsman LS (1960) A comparison of two methods of attitude measurement: Likert-type and forced choice. Educ Psychol Measmt 20: 699-704.

4. Shaw ME, Wright JM (1967) Scales for the measurement of attitudes New York: McGraw-Hill series in Psychology. USA. Exhibit 9-21. pp. 477-478. 